\title{
Thyroglossal duct cyst carcinoma
}

\author{
Mihail A. Boyanov', Dimitar A. Tabakov'², Radina S. Ivanova ${ }^{3}$, Kalin N. Vidinov ${ }^{2}$ \\ ${ }^{1}$ Clinic of Endocrinology and Metabolism, University Hospital Alexandrovska and the Department of Internal Medicine, \\ Faculty of Medicine, Medical University Sofia, Sofia, Bulgaria \\ ${ }^{2}$ Clinic of Endocrine Surgery, Clinical Centre of Endocrinology and Gerontology, Medical University of Sofia, Sofia, Bulgaria \\ ${ }^{3}$ Laboratory of Clinical Pathology, Clinical Centre of Endocrinology and Gerontology, Medical University of Sofia, Sofia, Bulgaria
}

Key words: thyroglossal duct cyst; papillary carcinoma; thyroid imaging; thyroid surgery

Thyroglossal duct cysts (TGDC) account for more than two thirds of congenital neck masses [1]. Thyroglossal duct cyst carcinoma (TGDCC) has been found in $0.7-1.5 \%$ of all cases of TGDC $[2,3]$. Since its initial description, a total of 250-300 cases of TGDCC have been reported as cases and case series of TGDCC [4-9]. A recent metaanalysis including 164 patients with TGDCC reported that $73.3 \%$ of the cases were found postoperatively [10]. However preoperative assessment by fine-needle aspiration biopsy (FNAB) and computed tomography (CT) is highly advocated $[11,12]$. Management of TGDCC is still a matter of debate, with the Sistrunk's operation being the basis of treatment [13-15].

A 17-year-old female presented with a painless midline neck mass. The patient noticed the mass growing for the last few months with no problems with swelling and no voice degradation. There were no symptoms or signs of thyroid dysfunction. On palpation the neck mass was firm but elastic and measured approximately $3 \mathrm{~cm}$ in diameter with an ellipsoid shape and moving during swallowing. No enlarged lymph nodes were palpable. There was no family history of thyroid cancer or prior neck irradiation. The ultrasound images of the midline neck mass are presented in Figure 1. The thyroid gland had a normal appearance on US, and no thyroid nodules or suspicious lymph nodes were found. No other diagnostic procedures were performed, and the patient was directly referred for surgery. The neck mass was removed with the preservation of the neck muscles and hyoid bone. The cyst had a well-defined capsule with no attachment to adjacent structures. No suspicious lymph nodes were found and removed. On pathology the cyst weighed $7.5 \mathrm{~g}$, measured $3 \times 2 \mathrm{~cm}$, and was well defined by a thick fibrous capsule. On microscopy there was a classical papillary carcinoma, with invasion of the cyst capsule and focal squamous cell metaplasia. The histology findings are presented in Figure 2. The tumour was staged pT2MxNx. The post-operative US follow-up revealed a completely normal thyroid gland, and no cyst residues or suspicious lymph nodes. A wait-and-see approach was adopted. Ten months later the thyroid gland and neck region appeared normal on ultrasound.

The data described in this case report were gathered retrospectively. The management of the patient was part of the routine clinical work-up. The subject and her parents have given their written, informed consent to publish the case.

We present a case of TGDCC in an adolescent girl incidentally discovered on histology with the surgical approach being minimally invasive. At least three questions remain open for discussion:

1. Is direct referral for surgery the best option? What is the place of FNAB?

2. Are there other imaging modalities beyond ultrasound that could have provided additional information?

3. Is minimally invasive surgery (preserving even the hyoid bone) an adequate approach?

As seen in Figure 1, there was a solid component in the cyst that did not show any vascularity on Doppler ultrasound. A FNAB of this component might have revealed its malignant nature and led to a more aggressive surgical approach. A publication, including 14 cases with a neoplasm in a TGDC, assessed the various methods for preoperative assessment [16]. In the five patients who underwent FNAB the diagnosis of a papillary carcinoma was made in only three cases [16].

Another possibility for further imaging is CT-examination $[9,12]$. It can reveal the solid component of the cyst (mural nodules) with possible calcifications as well as the adjacent structures and lymph nodes. In our 


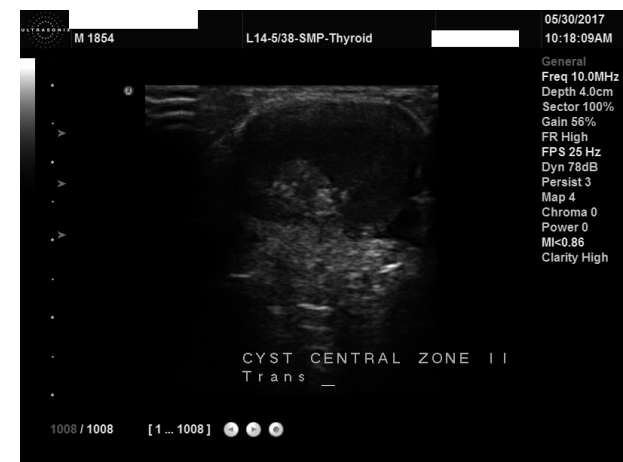

Figure 1. Basal ultrasound images of the thyroglossal duct cyst carcinoma (TGDCC) — transversal view (greyscale US). The solid component with multiple hyperechoic spots can easily be seen. The Doppler US did not reveal intra-nodular vascularisation, but a slow movement of the cystic fluid

case, a CT scan would have urged a more aggressive surgical approach.

However, the question remains open: how radical in such cases should the surgical approach be? Sistrunk's operation is the recommended first-line treatment $[5,13]$. There is also space for robot-assisted surgical removal of the cyst and thyroid gland [15]. Older publications found that the addition of total thyroidectomy did not significantly change the outcome [1]. Recent analyses advocate thyroidectomy among patients $\geq 45$ years of age and individuals with aggressive disease [10]. Others believe that thyroidectomy should be performed in all TGDCC patients [17].

In conclusion, the initial assessment of TGDC should be complex (ultrasound, US-guided FNAB, etc.), bearing in mind the rare possibility for a thyroid carcinoma within the cyst. The treatment provides challenges because the risk/benefit ratio of more radical approaches should always be carefully weighed.

\section{Disclosure statement}

The authors have no conflicts of interest to disclose

\section{Statements of ethics}

The research was conducted ethically in accordance with the World Medical Association Declaration of Helsinki. Data were collected retrospectively.

\section{Funding}

No funding was available.

\section{Competing interests}

None declared.

\section{References}

1. al-Dousary S. Current management of thyroglossal-duct remnant. J Otolaryngol. 1997; 26(4): 259-265, indexed in Pubmed: 9263896.

2. Klubo-Gwiezdzinska J, Manes RP, Chia SH, et al. Clinical review: Ectopic cervical thyroid carcinoma - review of the literature with il-

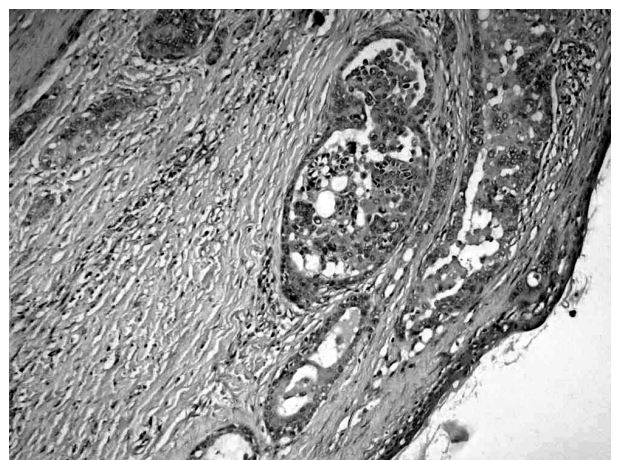

Figure 2. The histology of thyroglossal duct cyst carcinoma (TGDCC) in the 17-year-old female is shown. The fibrous capsule of the cyst with invasion by the papillary carcinoma can be clearly seen $(H E, \times 40)$. The presence of cystic papillary carcinoma with papillary cell structures and nuclear features typical for papillary thyroid carcinoma is displayed

lustrative case series. J Clin Endocrinol Metab. 2011; 96(9): 2684-2691, doi: 10.1210/jc.2011-0611, indexed in Pubmed: 21752893.

3. Forest VI, Murali R, Clark JR. Thyroglossal duct cyst carcinoma: case series. J Otolaryngol Head Neck Surg. 2011; 40(2): 151-156, indexed in Pubmed: 21453651.

4. Brentano H. Struma aberrata lingual mit druzenmetastasen. Deutsch Med Wschr. 1911; 37: 655.

5. LiVolsi VA, Perzin KH, Savetsky L. Carcinoma arising in median ectopic thyroid (including thyroglossal duct tissue). Cancer. 1974; 34(4): 1303-1315, doi: 10.1002/1097-0142(197410)34:4<1303::aid-cncr28203404 42>3.0.co;2-s, indexed in Pubmed: 4421377.

6. Olszewski J, Zieliński K, Miłoński J, et al. [Rare case of papillary cystic carcinoma of ectopic thyroid gland in glossothyroid ductus]. Otolaryngol Pol. 2005; 59(3): 437-439, indexed in Pubmed: 16117405.

7. Hilger AW, Thompson SD, Smallman LA, et al. Papillary carcinoma arising in a thyroglossal duct cyst: a case report and literature review. J Laryngol Otol. 1995; 109(11): 1124-1127, doi: 10.1017/s0022215100132207, indexed in Pubmed: 8551138.

8. Falvo L, Giacomelli L, Vanni B, et al. Papillary thyroid carcinoma in thyroglossal duct cyst: case reports and literature review. Int Surg. 2006; 91(3): 141-146, indexed in Pubmed: 16845854.

9. Ritzel RM, Bier J, Habermann CR. [Ductus Thyroglossal cyst carcinoma in a multicentric papillary thyroid carcinoma]. Rofo. 2013; 185(1): 76-77, doi: 10.1055/s-0032-1313211, indexed in Pubmed: 23023230.

10. Rayess HM, Monk I, Svider PF, et al. Thyroglossal Duct Cyst Carcinoma: A Systematic Review of Clinical Features and Outcomes. Otolaryngol Head Neck Surg. 2017; 156(5): 794-802, doi: 10.1177/0194599817696504, indexed in Pubmed: 28322121.

11. Yang YJ,Haghir S, Wanamaker JR, et al. Diagnosis of papillary carcinoma in a thyroglossal duct cyst by fine-needle aspiration biopsy. Arch Pathol Lab Med. 2000; 124(1): 139-142, doi: 10.1043/0003-9985(2000)124<0139:DOPCIA > 2.0.CO;2, indexed in Pubmed: 10629147.

12. Branstetter BF, Weissman JL, Kennedy TL, et al. The CT appearance of thyroglossal duct carcinoma. AJNR Am J Neuroradiol. 2000; 21(8): 1547-1550, indexed in Pubmed: 11003294.

13. Luna-Ortiz K, Hurtado-Lopez LM, Valderrama-Landaeta JL, et al. Thyroglossal duct cyst with papillary carcinoma: what must be done? Thyroid. 2004; 14(5): 363-366, doi: 10.1089/105072504774193195, indexed in Pubmed: 15186613.

14. Sistrunk WE. The surgical treatment of cysts of the thyroglossal tract. Ann Surg. 1920; 71(2): 121-122.2, doi: 10.1097/00000658-192002000-0000 2 , indexed in Pubmed: 17864229.

15. Byeon HK, Ban MJ, Lee JMi, et al. Robot-assisted Sistrunk's operation, total thyroidectomy, and neck dissection via a transaxillary and retroauricular (TARA) approach in papillary carcinoma arising in thyroglossal duct cyst and thyroid gland. Ann Surg Oncol. 2012; 19(13): 4259-4261, doi: 10.1245/s10434-012-2674-y, indexed in Pubmed: 23070784.

16. Doshi SV, Cruz RM, Hilsinger RL. Thyroglossal duct carcinoma: a large case series. Ann Otol Rhinol Laryngol. 2001; 110(8): 734-738, doi: 10.11 77/000348940111000807, indexed in Pubmed: 11510730.

17. Sturniolo G, Vermiglio F, Moleti M. Thyroid cancer in lingual thyroid and thyroglossal duct cyst. Endocrinol Diabetes Nutr. 2017; 64(1): 40-43, doi: 10.1016/j.endonu.2016.07.010, indexed in Pubmed: 27825535 . 